\title{
Las acciones populares en el proceso de codificación brasileño (con especial interés en Freitas y Beviláqua)*
}

\section{IVerónica Delgado Schneider**}

Resumen: este trabajo revisa cómo fueron concebidas las acciones (o interdictos) populares en el proceso de codificación civil brasileño del siglo xIx, y específicamente las romanas creadas para protección de algunas res publicae. Se intenta descifrar el pensamiento de Teixeira de Freitas, redactor, entre otras, del Esboço de un Código Civil para o Brasil y entender por qué, siendo partidario de ellas, no las incluyó en él. Por su parte, el redactor del Código Civil brasileño de I9ı6, Clóvis Beviláqua, no fue partidario de estos instrumentos, influenciado especialmente por la pandectística europea y por procesalistas italianos.

Palabras clave: acciones populares, Código Civil, Teixeira de Freitas, Clóvis Beviláqua, codificación.

Fecha de recepción: I3 de mayo de 20I6. Fecha de aceptación: 9 de octubre de 2016.

Esta publicación se relaciona al Proyecto CONICYT 2013, FONDAP n. ${ }^{\circ}$ I 5 I 30015 , Centro de Recursos Hídricos para la Agricultura y la Minería (CRHIAM), del cual la autora es investigadora asociada. Se agradece la colaboración del investigador Gamalier Caniuqueo Burgos.

Para citar el artículo: V. Delgado Schneider, "Las acciones populares en el proceso de codificación brasileño (con especial interés en Freitas y Beviláqua)", Revista de Derecho Privado, Universidad Externado de Colombia, n. ${ }^{\circ}$ 3I, julio-diciembre de 2016, 25-5I. DoI: http://dx.doi.org/I0.1860 I/or 234366.n31.02

** Doctora en Derecho de la Università degli Studi di Roma 'Tor Vergata', Roma, Italia. Profesora asociada en la Facultad de Ciencias Jurídicas y Sociales de la Universidad de Concepción, Concepción, Chile, en las asignaturas de Derecho Ambiental, Aguas y Derecho Urbano. Contacto: vedelgado@udec.cl 


\section{Popular Actions (Popular Injunctions) on the Brazilian Encoding Process (with Special Interest in Teixeira de Freitas and Clóvis Beviláqua)}

Авsтract: This paper analyzes the conception of popular actions and restraints in the Brazilian civil codification process of XIx century, specifically the roman actions created for the preservation of some res publicae. It tries to figure out the thought of Teixeira de Freitas, editor, among others, of the Esboço de un Código Civil para o Brasil and understanding why, being in favor of them, he did not include it. On his part, the editor of the Brazilian Civil Code of I9r6, Clóvis Beviláqua, was not in favor of these instruments, especially influenced by european pandectists and some Italian attorneys.

Keywords: Popular actions, Civil Code, Teixeira de Freitas, Clóvis Beviláqua, codification.

Sumario: Introducción. I. El fundamento de la popularidad en la Roma republicana: el concepto de "lo público". II. Roma imperial: la acción popular se debilita. III. La popularidad desaparece en los códigos civiles europeos y latinoamericanos. Iv. Las acciones (o interdictos) populares en Teixeira de Freitas. v. Las acciones (o interdictos) populares en Clóvis Beviláqua. vi. La influencia de la normativa y doctrina europea de la época en los argumentos de Beviláqua contrarios a la acción popular. Conclusiones. Bibliografía.

\section{Introducción}

Este trabajo tiene por objeto revisar cómo fueron concebidas y analizadas las acciones (e interdictos) populares en el proceso de codificación civil brasileño del siglo xIx, específicamente aquellas que desde el derecho romano existían para la defensa y protección de algunas res publicae.

Como se verá, estos instrumentos no fueron considerados en la codificación civil europea y en la mayoría de los códigos civiles latinoamericanos incluido Brasil, donde sólo el Código Civil de Bello (y aquellos códigos que siguen su modelo, como los de Colombia, Ecuador, El Salvador, etc.) considera, entre otras varias acciones populares, la posibilidad de que "cualquier persona del pueblo" pueda ejercer judicialmente ciertas y determinadas acciones (o interdictos) cuando se afecte el uso común o la seguridad en bienes nacionales de uso público en el artículo 948 c.c., como analizamos tiempo atrás, con ocasión de mis estudios de doctorado y una publicación en el aniversario número I 50 de nuestro Código Civil ${ }^{\mathrm{I}}$.

I La tesis de doctorado no está publicada. El trabajo al que hago referencia es Verónica Delgado

SchneIder, "La protección del medio ambiente a través de las acciones populares del artículo 
En la actualidad, en cambio, por medio de leyes especiales e incluso la propia Constitución Política de I988, Brasil incluye a las acciones populares como instrumento para la defensa del patrimonio público y del "medio ambiente", bien este último que se eleva coherentemente -y aquí está el fundamento de la popularidad-a un "bem de uso comum do povo".

\section{El fundamento de la popularidad en la Roma republicana: el concepto de "lo público"}

En el derecho romano la disciplina jurídica de las res publicae estaba centrada en quién es el propietario de las cosas, de tal manera que res publicae era sinónimo de res populi, expresión que a su vez estaba ligada a la noción de populus ${ }^{2}$ entendido como todos los ciudadanos. La cosa pública resultaba ser entonces la que pertenece al pueblo, esto es, la cosa de "todos los ciudadanos".

Analizando principalmente el Libro 43 del Digesto, Andrea Di Porto ${ }^{3}$ comprueba que las fuentes presentan un cuadro orgánico y rico de instrumentos eficaces para la protección de "algunas" res publicae, donde destaca el "interdicto4 popular”, es decir, aquel que puede ejercitarse por cualquiera del pueblo5. Estas

948 del Código Civil de Andrés Bello: un estudio histórico-comparativo", en Martinic, M. D. y Tapia, M. (eds.), Sesquicentenario del Código de Andrés Bello. Pasado, presente y futuro de la codificación, Santiago, LexisNexis, 2005, 907-937, del cual extraje los puntos 2, 3 y 4 .

2 En la doctrina romanista existen dos interpretaciones del sentido de la expresión "pueblo": a) una historiográfica sustentada por Jhering, Scialoja y Catalano, según la cual el pueblo se concibe como la pluralidad de ciudadanos ("todos los ciudadanos"), y b) una segunda que sostiene que el populus romanus desde el inicio de la época republicana tuvo una personalidad netamente separada de aquella de los singulares cives. Se identifica a la pluralidad de los ciudadanos como una entidad abstracta independiente de sus miembros, esto es, como una persona jurídica. La concepción romana de populus entra en la primera línea historiográfica: populus como pluralidad, nunca como persona jurídica. Si esta es la noción de populus, la noción de las res populi o publicae corresponde a la de las cosas que pertenecen al pueblo: a los ciudadanos. Para todo, ver Di Porto, A., "Interdetti popolari e tutela delle 'res in usu publico'”, en Aa.vv., Diritto e processo nell'esperienza romana. Atti del seminario torinese in onore di G. Provera (Torino, 4-5 dic. I99I), Università di Torino, Miscellanea dell'Istituto Giuridico I, Napoli, Jovene, I 994, 48 I; y FADDA, C., L'azione popolare. Studio di diritto romano ed attuale, Torino, Utet, 1894, 296.

3 Di Porto, A., "La tutela della 'salubritas' fra editto e giurisprudenza. I, Il ruolo di Labeone", Milano, Giuffrè, I990, I59.

4 Un interdicto es una orden de hacer o no hacer cualquier cosa que el pretor da, basado en su imperium, sea espontáneamente o a requerimiento de una persona determinada. Puede ser prohibitorio, restitutorio o exhibitorio. Se estima un instrumento administrativo. Ver explicación en Guzmán Brito, A., "Derecho privado romano", Santiago, Jurídica de Chile, 1996, t. I, I 92-193. Para el régimen general de los interdictos recomendamos SACCHI, A., "Interdicta", en Fiore, P. y Lucchini, L. (eds.), Il Digesto italiano, Torino, Utet, I902-I go6, vol. XiII, I 286-i 309 (I902-I 906); Salvatore Riccobono, "Interdicta", en Azara, A. y Eula, E. (eds.), Novissimo Digesto italiano, Torino, Utet, I962, vol. viII, 793-798; y Capogrossi Colognesi, L., "Interdetti", en Enciclopedia del Diritto, Milano, Giuffrè, I97I, t. xxI, 90 I-927.

5 Sobre los interdictos populares véanse los textos de SAcchi ("Interdicta") y de Riccoвono ("Interdicta"), citados, y Bruns, C., "Le azioni popolari romane", prefacio y trad. Vittorio 
res publicae resultan ser los lugares, calles, ríos y cloacas públicas, esto es, las cosas que constituyen la categoría de las res in usu publico o cosas de goce colectivo, incluidas las llamadas por Marciano "cosas comunes a todos los hombres", es decir, el aire, el agua corriente y el mar con sus costas ${ }^{6}$.

En otras palabras, los juristas romanos entienden que en la tutela de las cosas de uso público están en juego intereses que trascienden la esfera individual para alcanzar los del populus (entendido como "todos los ciudadanos") y, en consecuencia, junto a la autoridad, cualquiera de ese pueblo podrá tutelarlas. Las fuentes señalan, por ejemplo:

Dig. 43.7.I.I: pomponio; Comentarios a Sabino, libro xxx: "A cualquiera se le ha de permitir que pida respecto a lo público lo que le pertenece al uso de todos, como vías públicas y caminos públicos, y por esto se da interdicto a estas cosas a petición de cualquiera”.

Dig. 39.I.3.4: "si se construye una obra en terreno público, cualquier ciudadano puede hacer la denuncia de obra nueva”.

Dig. 43.8.2.2: "y con él [interdicto prohibitorio frente a obras en lugar público] se atiende tanto a las conveniencias públicas, como a las de los particulares, porque los lugares públicos sirven ciertamente para los usos de los particulares, a saber, por derecho de la ciudad, no como propios de cada uno; y tenemos tanto derecho para conseguirlo, como tiene cada uno del pueblo para impedirlo...”.

Para Bruns, la fundamentación manifiesta en Ulpiano Dig. 43.8.2.2 explica que cada ciudadano pueda actuar sin sufrir directamente un obstáculo en el uso de las cosas públicas. Sus derechos de hacer las reparaciones necesarias, de defenderlas contra las turbaciones, etc. están implícitos en un "derecho propio" a usarlas. En la popularidad, nos decía Paulo7, hay un "derecho propio" del pueblo, y como este no es un ente abstracto sino el pueblo efectivo, son todos los ciudadanos los que tienen el derecho a usar de las res publicae, y con los instrumentos populares no hacen más que defender este "universal" derecho ${ }^{8}$.

Scialoja, en Scialoja, V. (dir.), Studi giuridici, Roma, Anonima Romana Editoriale, I933, vol. I, y el citado prefacio.

6 Guzmán Brito explica que "Marciano habla de las 'cosas comunes a todos' y agrega que ello es por derecho natural. Tales son: el aire, el agua corriente y el mar con sus costas. D. I, 8, 2, pr-I e I. 2, I, pr-I. Pero ésta es una noción personal del citado jurista, influenciada por ideas estoicas, según las cuales el mar y el litoral marino son bienes que a todos pertenecen y que nadie puede apropiárselos en particular como de hecho ocurre con el aire”: GuzMán Brito, Derecho privado romano, cit., t. I, 434.

7 Dig. 47.23.I: "Paulo; Comentarios al Edicto, libro VIII.- Llamamos acción popular la que ampara el derecho propio del pueblo".

8 BRUns, "Le azioni popolari romane", cit., I64-165. 
Se trata -explica hace ya más de un siglo Vittorio Scialoja- de "derechos públicos difusos": públicos, pues corresponden al ciudadano como miembro del pueblo, y difusos, porque no le corresponden al pueblo como un ente distinto del ciudadano, sino a cualquiera de sus miembros 9 . El actor popular, en consecuencia, ejerce un derecho propio, que le pertenece, como a todos los ciudadanos, y que puede ser ejercitado singularmente por cualquiera de ellos. Y como indemnización a este derecho lesionado, el actor popular recibirá parte de la condena. No se trata de una recompensa por el servicio público prestado ${ }^{\mathrm{IO}}$.

Estas ideas hacen evidente lo que Di Porto llama la especial concepción de la popularidad romana republicana y que resume tan bien Jhering:

Esta era la perspectiva en la cual el antiguo romano veía al Estado. Lo que pertenecía al Estado, le pertenecía también a él. Las res publicae son las que él tiene en común con todos los demás, a diferencia de las res privatae que él tiene sólo para sí [...] La solidaridad, o mejor, la identidad de intereses de la comunidad y del individuo no podrían haberse expresado más claramente que en lo que sucede en el proceso romano con la actio popularis: el actor, defendiendo el interés del pueblo, defiende también el propio ${ }^{\text {II }}$.

Lamentablemente, con el Imperio cambiarán estas ideas y se apreciará una tendencia a la extensión de la esfera estatal (la autoridad) por sobre la privada (el actor popular), como se verá a continuación.

\section{Roma imperial: la acción popular se debilita}

En el derecho romano imperial las res publicae serán las cosas que al Emperador pertenecen.

Con una distinta concepción del bien público cambian también los instrumentos y los legitimados para exigir la tutela. El modelo de tutela fundado en el protagonismo del ciudadano se cambia por otro en el cual la protección corres-

9 Scialoja, prefacio a Bruns, "Le azioni popolari romane", cit., I 7.

IO Para Savigny las acciones populares eran "azioni di polizia, con rappresentanza popolare dello Stato", donde cada ciudadano podía proponer acciones populares como representante de la seguridad general, como procurador del Estado (gleichbsam als ein Procurator des Staats), sin la obligación de caución impuesta clásicamente al procurador privado. El actor popular era un Staatsanwalt (procurador del Estado) que ejercitaba un deber cívico general para tutelar un interés público, político, de policía, moral; y como premio a toda esta actividad realizada en el público interés se le atribuía la mitad de la pena. Es Fadda quien explica el pensamiento de Savigny (FADDA, L'azione popolare. Studio di diritto romano ed attuale, cit., 30I. Por el contrario, para aquellos que, como Scialoja, sostienen que el actor popular ejerce un derecho propio, recibiría una compensación por su derecho lesionado. Ver Scialoja, prefacio a Bruns, Le azioni popolari, cit.).

i I Von Jhering, R., Lo scopo nel diritto, trad. Mario G. Losano, Torino, Einaudi, i972, 393, citado por Di Porto, "Interdetti popolari e tutela delle 'res in usu publico", cit., 499. Todas las traducciones de citas textuales de obras en otros idiomas son propias. 
ponde básicamente a la administración imperial y el rol del ciudadano pierde poder y espacio limitándose, según las fuentes, a las cosas menos importantes (las del campo). La protección de la ciudad, en efecto, pasa en un primer momento a la curia de los curatores (curator de los ríos, de las vías urbanas, de las cloacas), y luego estos son substituidos por la Administración Imperial ${ }^{\text {I2 }}$.

\section{La popularidad desaparece en los códigos civiles europeos y latinoamericanos}

En la mayoría de los Estados nacionales europeos los códigos civiles no consideraron la tutela popular de las res in usu publico ni siquiera en forma complementaria a la defensa estatal. El Estado se erige como el propietario de ellas y, con esto, en su protector exclusivo.

Para explicar dichos cambios conceptuales y el abandono legislativo e inclusive doctrinario por las acciones e interdictos populares, Di Porto aduce dos razones: la noción abstracta del Estado y la influencia de la pandectística ${ }^{\mathrm{I}}$.

Así pues, habría sido determinante la construcción de una noción abstracta del Estado como una persona jurídica, como una entidad separada de los ciudadanos que la constituyen, en la que el concepto de res publicae pierde definitivamente el nexo con el pueblo y pasa a ser aquella "estatal”, en la cual los ciudadanos tendrán un uso común, porque la autoridad lo "concede" ${ }^{4} 4$ y, por ende, sólo el Estado puede proceder por vía administrativa como representante de cada público interés en contra de actos que perturben tal uso común. La acción de un "privado" no puede tener lugar sino cuando también su "privado" interés (su propiedad, su integridad personal) haya sido lesionado en cualquier modo. El Estado absoluto -dirá Bonfante- basado en un "ordenamiento burocrático, centralístico y en la inercia de los ciudadanos" los excluirá de toda participación ${ }^{15}$. Un Estado así concebido -coincide Jhering- "no puede sino monopolizar todo aquello que sea considerado público"I6.

I2 Di Porto, "Interdetti popolari e tutela delle res in 'usu publico"”, cit., 5 I9; e Íd., "O papel do cidadão na tutela do ambiente", Revista Brasileira de Direito Comparado, Rio de Janeiro, vol. I 2 (I992), I 54 .

I 3 Di Porto, "Interdetti popolari e tutela delle 'res in usu publico", cit., 499.

I4 Así lo explica también Carl Bruns: con la moderna distinción abstracta del Estado y de los súbditos, generalmente limitamos el derecho de uso de los ciudadanos sobre las res publicae en modo tal que resultan ser de propiedad del Estado, por cuanto es este el que "concede" al público el uso común. Y ejemplifica: "El derecho territorial prusiano expresa directamente este concepto: 'Le vie di campagna, i fumi, il lido del mare e i porti sono comune proprietà dello Stato'; 'E concesso a tutti l'uso delle vie per viaggiare ecc.'; 'La navigazione sui fiumi è permessa a tutti'. Ver II, I4, 2 I, 26; I 5, 7, 44, 47. Símil al Código Civil austríaco \$287" (Bruns, "Le azioni popolari romane", cit., I65).

I 5 Bonfante, P., Istituzioni di diritto romano, $4 \cdot{ }^{\text {a }}$ ed., Milano, Vallardi, I932, 463.

i6 En Von Jhering, R., Lo scopo nel diritto, cit. por Di Porto, "Interdetti popolari e tutela delle 'res in usu publico'", cit., 499. 
En segundo lugar, la doctrina romanista dominante de los siglos xix y xx, bajo la influencia de las categorías de la pandectística y especialmente de Mommsen, habría "desmantelado" los instrumentos populares "forzando las fuentes romanas del Corpus Iuris para servir a las exigencias alemanas de la época" ${ }^{17}$. Así, por ejemplo, el análisis de las obras de Glück, Dernburg y Windscheid ${ }^{18}$ demuestra cómo algunos interdictos o acciones que eran populares en el derecho romano se transformaron en el derecho germánico en meras "denuncias"; que se negaba la existencia de los "anticuados" interdictos populares, recalcando que las nuevas leyes (especialmente penales o administrativas) dejaban la protección de las cosas de uso público sólo a las autoridades; y que un particular podía actuar únicamente mientras tuviera un interés personal comprometido. Se destacaba además que en Alemania, si bien el uso era común, las cosas públicas eran de propiedad del Estado (y no del pueblo, como en Roma) y el uso (que "concede" la autoridad a los ciudadanos) está regulado por normas de policía que no pertenecen al derecho privado ${ }^{19}$.

$\mathrm{Y}$ así fue como entonces en el derecho moderno europeo los interdictos populares para la tutela de los bienes de uso común no se mantuvieron. Los códigos civiles, por ejemplo, excluirán tratar todo lo relacionado con este tipo de bienes (dejando la regulación al derecho administrativo donde sólo el Estado tutela y el particular, a lo más, tiene derecho a denunciar); en materia de daños o de relaciones de vecindad se exigirá siempre al actor la lesión directa de sus bienes o integridad (y con ello desaparece la popularidad) o bien, por ejemplo, respecto a las acciones populares propias de los cuasidelitos (actio de positis vel suspensis y diectis vel effusis), ellas serán reducidas en los códigos civiles a meras denuncias a la autoridad o simplemente no serán consideradas en el proceso de codificación ${ }^{20}$.

I 7 Di Porto, ob. cit., 503 ss.

i 8 Nos referimos a la obra de Friedrich von Glück, Ch., Commentario alle Pandette, trad. G. Fadda y P. Cogliolo, Milano, Società Editrice-Libraria, I905, L. XLIII, parte IV, 337 ss.; de Dernburg, H., Pandette, trad. ital. de la 6. ${ }^{\text {a }}$ ed. por F. Cicala, Torino, Fratelli Bocca, I906, vol. I, n. ${ }^{\text {o }}$ I, 39 I, y de Bernard Windscheid, Diritto delle Pandette, trad. ital. C. Fadda y P. E. Bensa, Torino, Utet, I904, 2, y 457, 367 y n. ${ }^{\circ}$ 4, citados por Di Porto, "Interdetti popolari e tutela delle 'res in usu publico", cit., 504 .

i9 Para esta última afirmación ver, p. ej., Windscheid, B., Diritto delle Pandette, trad. ital. de C. Fadda y P. E. Bensa y continuada por Bonfante, ayudado por Maroi, Torino, Utet, I92 5, vol. I, parte II, 25-27.

20 Así puede comprobarse, tanto para el derecho europeo como para el latinoamericano, en Schipani, S., "Actio de positis aut suspensis", en Schipani, S. (dir.), Derecho romano y unificación del derecho, Experiencia europea y latinoamericana (con especial atención a la responsabilidad extracontractual), Materali II, Roma, Univerità 'Tor Vergata', I999, I45-I50, y en Schipani, S., "Actionis de deictis vel effusis", en Schipani (dir.), Derecho romano y unificación del derecho, cit., I 5 I-I 76 , respectivamente, extraídos de las voces respectivas en López Cabana, R. y Alterini, A. (dirs.), Enciclopedia de la responsabilidad civil, Buenos Aires, Abeledo-Perrot, I996, t. I. 
Los códigos latinoamericanos no escaparon a esta influencia, aunque, entre ellos, el Código de Bello será una preciosa excepción ${ }^{21}$.

Este trabajo está destinado entonces a revisar cómo fueron analizadas y concebidas las acciones (e interdictos populares relacionados a las res publicae) en el proceso de codificación brasileño.

\section{Las acciones (o interdictos) populares en Teixeira de Freitas}

No se puede analizar la codificación brasileña sin detenerse en las obras del gran romanista $^{22}$ Teixeira de Freitas; y en el tema que nos ocupa resulta más bien imperioso dado que, como veremos, fue citado (¿justa o injustamente?) por Clóvis Beviláqua frente a la comisión encargada de la revisión del Código Civil, para justificar su propuesta de no consagrar en él instrumentos populares.

Como se sabe, Teixeira de Freitas fue el autor de la Consolidação das Leis Civis de 1858 , obra que, sin tener fuerza de ley, "hizo las veces de un código" hasta que este entró en vigor en I919 ${ }^{[23]}$. Encargado más tarde también el jurista de la codificación, en r 860 empieza a entregar sus proyectos como Codigo Civil. Esboço, hasta que en 1863 la Comisión Revisora del Gobierno suspende su labor. En su tarea examinó un amplio material: todos los códigos existentes en su época, el derecho romano, y una extensa literatura jurídica, especialmente la alemana y la francesa. "El Esboço constituye un unicum en la historia de la codificación americana, por su originalidad, por haberse adelantado en sus concepciones a resultados posteriores y por haber sido el primer trabajo sobre la materia que dio entrada a un sistema, si no calcado, al menos inspirado en el espíritu de la Pandectística alemana. En contraste, le perjudicaron su desmedida longitud y su doctrinarismo" 24 .

En estas páginas pretendemos descifrar la concepción que el jurista propuso de las res publicae y de los instrumentos populares.

2 I Delgado Schneider, "La protección del medio ambiente a través de las acciones populares del artículo 948 del Código Civil de Andrés Bello", cit., 907-937.

22 A este respecto véase Moreira Alves, J. C., "A formação romanística de Teixiera de Freitas e seu espíritu inovador", en Schipani, S. (dir.), Augusto Teixeira de Freitas e il diritto latinoamericano, Atti del Congresso di Roma, I, Padova, Cedam, I988, 4I-50, especialmente I9-25.

23 Teixeira de Freitas, A., Consolidação das Leis Civis, Rio de Janeiro, Typographia Universal de Laemmert, I 857, 527. Sobre la idea de "consolidar" y "codificar" el derecho (en Teixeira de Freitas) véase Guzmán Brito, A., Pecorella, C. y Baptista Villela, J., en Schipani (dir.), Augusto Teixeira de Freitas e il diritto latino-americano, cit.; y especialmente Schipani, S., "Dal diritto romano alle codificazioni latinoamericane: l'opera di A. Teixeira de Freitas (Prime osservazioni sulla nozione di 'Consolidação' e sulla sistematica dei 'fatti')”, en Società Sassarese per le Scienze Giuridiche (ed.), Studi Sassaresi, serie 3, n. ${ }^{\circ}$ 5: Atti del Colloquio internazionale sul Diritto romano, Codificazioni e unità del sistema giuridico latino-americano (1977-78), Milano, Giuffrè, I981, 589 ss.

24 Guzmán Brito, A., La codificación civil en Iberoamérica. Siglos XIX y XX, Santiago, Jurídica de Chile, 2000,500 . 
Desde ya adelantemos que ni en la Consolidação ni en su Esboço Teixeira de Freitas trata ni propone, respectivamente, la utilización de instrumentos populares para la tutela del uso común de las res publicae.

Respecto a la concepción de las res publicae, en la Consolidação el jurista distingue los bienes “de dominio nacional”, los bienes nacionales propios ${ }^{25}$, los bienes provinciales $^{26}$, municipales y de dominio particular ${ }^{27}$. A su vez, dentro de los bienes de "dominio nacional" incluye las cosas de uso público ${ }^{28}$, las cosas de dominio del Estado ${ }^{29}$ y los bienes de la Corona ${ }^{30}, y$, finalmente distingue, dentro de los bienes municipales, aquellos propios del patrimonio de ciudades o villas y aquellos de uso común de sus moradores ${ }^{3 \mathrm{I}}$. O sea, reconoce expresamente la existencia de las "cosas de uso común" del pueblo o de los moradores de una ciudad o villa, pero al mismo tiempo anota que en la legislación del Imperio (Ord. L..$^{\circ}$ T. $26 \$ 8$ ), no obstante que el uso pueda ser común a la gente, siempre la propiedad quedará en el "patrimonio real" ${ }^{2}$. Por otra parte, en cuanto a

25 En el art. 59: "São próprios nacionais os bens como tais incorporados, ou assentados nos Livros deles; isto é, os que se adquiriram para a Fazenda Nacional por algum titulo; ou em virtude de Lei; em cujo número entram as fortalezas, fortes, castelos, baluartes, cidadelas, com todos os seus pertences".

26 En el art. 6o: "Distinguem-se das espécies acima declaradas os bens provinciais, cuja administração é regulada pelas Assembleias Legislativas das Provincias".

27 En el art. 62: "Os bens do domínio particular são alodiais ou enfitêuticos".

28 Art. 52 I: "As coisas de uso publico, como estradas e ruas públicas; rios navegáveis, e de que se fazem os navegáveis, se são caudais, que correm em todo o tempo (13) e igualmente os portos de mar, onde navios costumam ancorar (I4)". A su vez, en la nota I 3 se cita "Ord. L. $2^{\circ}$ T. 26 \$ 8.- E posto que (palavras da Lei) o uso das estradas e ruas públicas, e dos rios, seja igualmente comum a toda a gente, sempre a propriedade fica no Patrimônio Real. Esta Ord., com todos os seus parágrafos sobre os direitos da soberania, que outrora denominavam-se Direitos Reais, foi transcrita do Cap. 237 das Ordenações da Fazenda de I7 de Outubro de I 5 I 6, que vêm no Volume do Sist. dos Regimentos". Agrega: "Ha estradas, que não pertencem à administração geral do Estado, sobre as quais legislam as Assembleias Provinciais - Acto Add. Art. Io \$ 8". Y además: "Elas também legislam sobre a navegação de rios no interior das Províncias, que não pertençam à administração geral do Estado - Acto Add. loc. cit."; y finalmente, en la nota I4 señala: "Cit. Ord. L $2^{\circ}$ T. $26 \$$ 9. Estão no mesmo caso as praias, o mar e os 'mares territoriais' ou adjacentes em tanta distância, quanta abranger o tiro de canhão - Alv. de 4 de Maio de I $805 \$ 2^{\circ}$. Mas as praias do mar, compreendidas nos chamados terrenos de marinhas, pertencem em grande parte ao domínio particular, salvo o direito do Estado".

29 Art. 52 II: "As coisas do domínio do Estado, como ilhas adjacentes mais chegadas ao território nacional, terrenos de marinhas, mares interiores, além do porto onde as marinhas terminam; quaisquer acumulações de terras casuais ou artificiais, que assentam sobre o fundo do mar, terras devolutas, minas ou terrenos diamantinos, páo-brazil, bens a que não é achado senhorio certo [sic]; os do evento; aqueles, cujo dono faleceu sem testamento, não deixando parentes até o décimo grau segundo o Direito Civil; ou com testamento, se os herdeiros repudiam a herança; todas as embarcações, que se perderem, e derem à costa nas praias do Império; e seus carregamentos, sendo de inimigos, ou corsários; e os próprios nacionais".

30 Art. 52 III: "Os bens da Coroa; a saber: palácios, terrenos nacionais, e construções, que pertencem ao Imperador, e a seus sucessores".

3 I En el art. 6I se prescribe: "Distinguem-se igualmente os bens municipais, cuja administração, e conservação, pertence às câmaras das Cidades, e Vilas; tanto os próprios do seu patrimônio, como os do uso comum dos moradores".

32 Anota Teixeira de Freitas: “Ord. L. $2^{\circ}$ T. 26 S 8.- E posto que (palavras da Lei) o uso das estradas e ruas públicas, e dos rios, seja igualmente comum a toda a gente, sempre a propriedade fica no Patrimônio Real". 
la tutela de las mismas, el artículo 6r de dicho texto señala que son las Cámaras de las ciudades o villas, las encargadas de la administración y "conservación" de las cosas de uso común de los moradores. No hay alusión alguna a instrumentos populares.

El Esboço será un tanto más ilustrativo a nuestros fines. En primer lugar, para Teixeira de Freitas -apartándose del derecho romano- las llamadas "cosas comunes a todos los hombres" de Marciano (aire, luz y mar) no se reputarían cosas (o bienes) en el sentido del Código pues no serían susceptibles de una medida de valor ${ }^{33} \mathrm{y}$, en consecuencia, tampoco serían bienes susceptibles de propiedad 34 . O sea, para él existe esta categoría de cosas comunes a todos.

En segundo lugar, mantiene la clasificación de los bienes, que serán nacionales y particulares. Según el artículo 326 son bienes nacionales: I. ${ }^{\circ}$ las cosas públicas (art. 274 n. ${ }^{\circ} \mathrm{I}$ ), que a su vez podían ser susceptibles de apropiación (res nullius) o bien de uso gratuito (res in usu público); $2 .^{\circ}$ los bienes de la Corona (art. 274 n. ${ }^{\circ}$ ); $3 .^{\circ}$ los bienes generales (art. 274 n. ${ }^{\circ}$ ); $4 .^{\circ}$ los bienes provinciales (art. $274 \mathrm{n}^{\circ}{ }^{\circ}$ ), y $5 .^{\circ}$ los bienes municipales (art. $274 \mathrm{n}^{\circ}{ }^{\circ}$ 4). Sin embargo, al comentar la categoría de las res in usu publico, el jurista aclara que el propietario de estos bienes es el "povo, em geral como entidade política", y que no pudo ser otro el "pensamento" del parágrafo 8 citado que, no obstante, los considera "patrimonio real".

Pese a esta declaración, sin embargo, no consagra acciones populares para su defensa. Es más, en el artículo 328 del Esboço -que enumera las cosas públicas susceptibles de uso gratuito, donde el jurista incluye los terrenos, caminos, calles, plazas, canales, puentes públicos, etc.- se enfatiza en que las cosas estén "a cargo"

33 Dispuso el art. 318: "Os objetos materiais, que sendo necessários ou úteis, não forem suscetíveis de uma medida de valor, como o ar, a luz, o mar, não se reputam coisas no sentido deste Código". Y al comentar esta norma TeIXeIra de Freitas anota: "O direito romano, quando considera as coisas em sua existência natural, compreende em geral tudo o que existe corporalmente no espaço, não sendo pessoa; e portanto todas as partes componentes da natureza não livre. Como existem coisas que não são suscetíveis da apropriação, o Direito Romano denomina coisas comuns -res communes omnium hominum-, e daí resulta a diferença entre coisas e bens. Neste projeto, estas duas palavras são sinônimas, as coisas comuns ficam fora da linha das coisas; porquanto se trata das coisas como elemento de direitos, e os objetos materiais comuns e inexauríveis não são elemento de direitos. O projeto, portanto, vai de acordo com a teoria dos economistas modernos, que só reputam valor o valor permutável, e não a simples utilidade que se tem chamado valor de utilidade. Ora, tudo o que é suscetivel de valor é suscetível de apropriação, tudo o que tem valor é propriedade; e quando não tem valor, quando não é coisa, porque não pode ser elemento de direitos".

34 Art. 320: "Mas estes outros objetos, e igualmente as coisas, terão o nome de bens. Em seu complexo, os bens formam o patrimônio das pessoas, e constituem toda a riqueza nacional ou particular". Comentando esta norma precisa que no serían susceptibles de propiedad y que "[t]odas as coisas são bens porque, excluídos os objetos materiais do art. 3 I 8 res communes, todas as coisas são suscetíveis de propriedade, e por isto mesmo têm proprietário. As que não pertencem aos particulares são bens nacionais. Este é o sistema do Direito Francês, e assim não temos res nullius no sentido do Direito Romano, como coisas que não pertencem a ninguém, e a ninguém podem pertencer, a não serem as res communes do art. 3 I 8". Y agrega: "As coisas públicas são somente suscetíveis de uso gratuito (art. 328), que pelo Direito Romano eram também res nullius, a par das res communes, são consideradas no Projeto (art. 326, $n^{\circ}$ I) uma espécie de bens nacionais". 
de las Cámaras Municipales o "a cargo" del Gobierno General o del Gobierno Provincial o de las Cámaras Municipales respectivamente, sin aludir de manera expresa a la colaboración de cualquiera del pueblo al efecto.

Sin embargo, serán las notas que Teixeira dedicó a la obra Doutrina das ações del conocido jurista portugués José Homem Corrêa Telles y que acomodó al Foro de Brasil las que ilustrarán decididamente nuestra investigación con alusiones directas al uso de la institución que nos ocupa ${ }^{35}$.

La obra de Corrêa Telles comienza con una clasificación de las acciones, en donde se lee: "Açoes populares são as que podem ser intentadas por qualquer pessoa do povo, para conservação ou defesa de coisas públicas" ${ }^{6}$. A su vez, la nota I $3^{[37]}$ reza claramente: "Nada obsta a qualquer pessoa do povo poder demandar contra a usurpação de coisas de uso público, ou embargar a obra nociva ao lugar público, como a rua, o mar, o rio público". El jurista, pues, se muestra partidario de la acción popular y su existencia para la tutela de las cosas de uso común.

En lo que no está de acuerdo, sin embargo, es en la definición recién transcrita -y esta será la frase más tarde citada por Clóvis Beviláqua- al agregar:

Add. Qualificar as Ações populares, só no aspecto do fuizo Civil, para conservação ou defesa de coisas públicas, é restringir sem exatidão a ideia; havendo as conbecidas Ações populares, ou públicas, do fuizo Criminal, de que tratam, a Constituição do Império no Art. $157^{[38]}$ e o Cód. do Proc. Crim. ${ }^{39}$ Daí o aditamento da Sétima Edição de Laemmert sobre a nossa Legislação Criminal neste assunto; aditamento fora de propósito, e inútil.

35 No tuvimos la oportunidad de revisar los comentarios que hizo a la obra de Caetano Pereira e Souza, J. J., Primeiras linhas sobre o Processo Civil, Lisboa, Typographia Rollandiana, r863, donde se pudo tratar el tema.

36 Homem Corrêa Telless, J., Doutrina das accões [acomodada ao Fồro do Brazil por A. Teixeira de Freitas], Rio de Janeiro, H. Garnier, I902, \$ I I, I I.

37 En Ferreira Coelho, A., Codigo Civil dos Estados Unidos do Brasil. Comparado, comentado e analisado, Rio de Janeiro, Jornal do Brazil, I925, I 23, y Pinto Ferreira, L., voz "ação popular", en Enciclopédia Saraiva do Direito, coord. R. Limongi França, São Paulo, Saraiva, I977, vol. I, 370, analiza el punto partiendo de la base de que la nota es de autoría de Teixeira de Freitas. Por el contrario, sería de Corrêta Telles, J. H., se deduce en Carvalho Santos, J. M. (dir.), Repertório Enciclopédico do Direito Brasileiro, coadyuvado por de Aguiar, J., Rio de Janeiro, Borsoi, I947, vol. II, 2 I6.

38 Ferreira Coelho, Codigo Civil dos Estados Unidos do Brasil, cit., I23 y i24, informa que la Constitución del Imperio, después de establecer en el artículo ${ }_{5} 6$ la responsabilidad de los jueces de derecho y de los oficiales de justicia, por los abusos de poder y la prevaricación que cometieran en el ejercicio de sus empleos, dispuso en el artículo i57 que contra ellos procedía acción popular por el afectado o cualquiera del pueblo por soborno y otros delitos similares. Sin embargo, en la misma obra (p. I 24) se transcribe el comentario a la norma del jurista PIMENTA BuENo, para quien esta "denuncia" (no dice acción) popular se justifica en que los hechos son de aquellos que quebrantan vergonzosamente la moralidad pública.

39 Ferreira Coelho, Codigo Civil dos Estados Unidos do Brasil, cit., I 24, transcribe a su vez el artículo I 50 del Código de Proceso Criminal brasileño de 1832 que establecía el derecho de "todo ciudadano" para "denunciar" a la autoridad competente a cualquier empleado por "crímenes de responsabilidad", para que se proceda contra ellos en conformidad a la ley. 
¿Qué quiso decir? Primero, que la definición de Corrêa Telles resultaba restringida y poco exacta pues no sólo debía considerarse la protección de las cosas de uso común (como se establecía) sino que también debía considerarse el objeto protegido por las acciones populares existentes en la nueva República en materia criminal y que, de acuerdo a las disposiciones citadas, existían para perseguir ciertos crímenes de funcionarios públicos considerados atentados a la moralidad pública. Segundo, y en lo que nos interesa, el jurista coincide en que no existe impedimento alguno para el ejercicio de las acciones populares destinadas a la usurpación y conservación de las cosas públicas, incluyendo en ellas, justamente -como diría Di Porto-, aquellas cosas públicas destinadas al uso común, como calles, mar, ríos y lugares públicos.

Confirman nuestra conclusión, siempre en el mismo libro, pero ahora al tratar de una obra nueva, las palabras del propio jurista: "Add. Quando a nova obra for prejudicial a algum lugar público, qualquer pessoa pode embargá-la..."40. Hay acción popular, al igual que en el derecho romano.

Sin embargo, la frase que sigue a esta afirmación ("maiormente tendo para isso algum interesse particular") ha motivado ciertas aprehensiones ${ }^{4}$, a nuestro juicio injustificadas pues aquí Freitas no hace más que consagrar una regla general (procede acción popular) y una regla especial (si existe "particular interesado", este debe ser preferido a la hora de ejercer la acción). Y su explicación en la nota respectiva es clara al respecto: si bien los lugares públicos en la época se reputan del dominio y uso común del pueblo o de dominio del Estado, se debe considerar que, respecto a los terrenos de las marinas y los acrecimientos marítimos o fluviales, la legislación reconoció ciertos derechos de preferencia, por lo cual “..é indispensável reconbecer em juizo tais direitos de preferência, e nos particulares interessados a facultade de proporem suas Ações de embargo de obra nova" ${ }^{2}$. Por lo demás, ya sabemos que en el régimen general de las acciones populares siempre se debía preferir a aquel que pudiese tener un interés más directo ${ }^{43}$.

40 Corrêa Telles, Doutrina das accões, cit., I65.

4 I Carvalho Santos, Repertório Enciclopédico do Direito Brasileiro, cit., 2 I6, opina que con el ejemplo que dio Freitas se restringe la "amplitud ilimitada" con que acepta la institución Corrêa Telles pues la preferencia restringe el derecho a la acción, haciéndolo dependiente de una situación jurídica especial.

42 Teixeira de Freitas, cit. por Corrêa Telles, Doutrina das accões, cit., I65, señala textualmente en la nota 459: "É o mais atualmente que pode ter lugar, quando as obras novas são nocivas por qualquer motivo a lugares públicos: ou se reputam do domínio e uso comum do Povo, ou do domínio do Estado; como são hoje, por mais saliente exemplo, os terrenos de marinhas, e acrescidos marítimos ou fluviais. Como sobre essa propriedade pública de marinhas a nossa Legislação moderna tem outorgado os direitos de preferência coligidos no Art. 613 da Consolidação das Leis Civis, extensivos aos acrescidos pelo Decr. N. 4105 de 22 de Fevereiro de I868; é indispensável reconbecer em juízo tais direitos de preferência, e nos particulares interessados a faculdade de proporem suas Ações de embargo de obra nova".

43 Según Bonfante, Istituzioni di diritto romano, cit., I I3, si intentaran interponer una misma acción varias personas, el pretor la otorgaba preferentemente al que justificaba tener un interés más directo para ejercitarla, y si no lo hubiera, a quien él considerase más apto o idóneo. 
No obstante lo aquí dicho, a la hora de evaluar estas conclusiones se debe tener presente cuanto sigue: siempre en el mismo libro, Freitas utiliza nuevamente la expresión "particular interesado" respecto a las acciones enderezadas a solicitar la demolición de ciertas obras; acciones que, de acuerdo a las vigentes normas de la nueva república, corresponderían además a las Cámaras Municipales ${ }^{44}$, es decir, serían dos los legitimados: el particular interesado y la autoridad. También en su Esboço, frente a una obra ruinosa, prohibió exigir judicialmente la caución por los eventuales daños disponiendo que para evitar el daño sólo se pudiera requerir las "medidas policiales" que correspondan45; es decir, nuevamente la solución la daba la autoridad. Y respecto al deterioro de la calidad del aire (con humos, exhalaciones, infecciones o infiltraciones nocivas), limitó las acciones a los "vecinos perjudicados" ${ }^{6}$. Claro que a nuestro favor juega el que, en todos estos casos (a diferencia de los analizados más arriba), el autor no discurrió expresamente sobre la base de daños o temor de daños en las cosas comunes a todos los hombres o las res in usu publico.

De lo dicho, pues, nos parece que Teixeira de Freitas conocía y aprobaba la aplicación de los instrumentos populares romanos para la tutela de las res in usu publico, ciertamente con algunas limitaciones (cuando existe lo que llamó un "derecho de preferencia")47.

Recordemos que, por ejemplo, en la actio deictis vel effusis, establecida para que sin miedo y in peligro se transite por calles y caminos, es decir, para la seguridad de los transeúntes, en caso de homicidio o herida de un hombre libre, si bien la misma era popular (correspondiendo a cualquiera del pueblo), "debía darse principalmente al que le interesa o al que es pariente del difunto por afinidad o por cognación" (Dig. 9.3.5.5). Para un completo análisis, desde el derecho romano hasta nuestros días, incluyendo el derecho europeo y el latinoamericano, véase Schipani, "Actionis de deictis vel effussis", cit.

Teixeira de Freitas, A. en Corrêa Telles, Doutrina das accões, cit., i67 y i68. Trata de la Acção de damno infecto en el $\$ 90$, y en la nota 468 respectiva explica que esta acción procede cuando exista temor de ser damnificado por una casa ruinosa del vecino, o vicio de obras o por hechos de un vecino. Como ejemplo de hechos de terceros se incluye el caso en que en la casa del vecino hay "grande fumo que impeça o uso do ar livre". El autor anota que, de acuerdo a la normativa vigente -que detalla-, la demolición de obras ruinosas no puede ser hoy ordenada por ningún juez de oficio sino que sólo puede ser decretada a solicitud de los abogados o procuradores de las respectivas "autoridades" (Cámaras Municipales) o de los "particulares interesados". Además, en p. I66, se comprueba que frente a daños tales como "[s]e no tanque alheio, ou no rio, lançou veneno, ou imundícia, que a água corrompesse" (nota 467 n. ${ }^{\circ} 5$ ) la legitimación activa de la acción demolitoria se confiere a quien tenga un "interés" o un "derecho", es decir, quien sea "perjudicado", por ejemplo, en el ejercicio de una servidumbre, sin importar si la obra estuviese o no en un lugar público. En el $\$ 89$ se lee: "Ação demolitória: Compete a quem tenha interesse em não ter-se feito alguma obra nova, que lhe-é prejudicial...", y en la nota 460 agrega: "Que a obra fosse feita em terreno público, ou do Réo, não importa [sic]; uma vez que haja prejuizo de alguma servidão do Autor ou de outro seu direito (nota 459)".

Esboço, art. 3695 .

46 Esboģo, art. 4233 .

47 Pinto Ferreira, voz "ação popular", cit., 370, coincide en que Freitas admitía el ejercicio de la acción popular para la conservación de las cosas de uso común del pueblo. Sin embargo, este 
Sin embargo, no hemos logrado dilucidar por qué, a la hora de consolidar y codificar la legislación brasileña, prescindió de ellos. Con todo, hay un dato importante a considerar: buscando sólo codificar el derecho civil, Freitas excluirá de sus obras todo lo relativo a las acciones $4^{4}$.

\section{Las acciones (o interdictos) populares en Clóvis Beviláqua}

Con la República, Brasil logra la codificación civil, obra del profesor de derecho comparado de la Facultad de Derecho de Recife, Clóvis Beviláqua, sancionado como Código Civil Brasileño el r. ${ }^{\circ}$ de enero de i9r6. El sistema del código es de "clara inspiración pandectística" pero en su contenido "se mantuvo dentro de la tradición del derecho patrio", pues en su elaboración se disfrutaron las obras de Freitas que eran "expresión bastante fiel del derecho lusitano-brasileño" 49.

En este código, los bienes de uso común del pueblo son "bienes públicos", en el sentido de pertenecientes al "dominio nacional de la Unión, los Estados o Municipios" $5 \circ$. Y, en cuanto a la tutela, si bien existen, por cierto, numerosas disposiciones que aseguran, por ejemplo, la limpieza de ríos, cloacas y canales, o la cesación de molestias originadas en humos o aguas estancadas, etc., todas ellas operan bajo el supuesto de que la molestia, perturbación o daño involucra un derecho o interés particular del vecino, del titular de una servidumbre o de algún otro derecho protegido por la ley. No hay lugar para acciones populares.

autor no hace hincapié en que el mismo jurista señala que deben aceptarse como tales también algunas acciones criminales dictadas a la época.

48 Ver lo que el jurista señala al respecto en los títulos XII y xiı de la Introducción de la Consolidação das Leis Civis, cit., obra que, en efecto, tenía como uno de sus objetivos consolidar las leyes para fijar los límites del derecho "civil" y así poder trabajar en la codificación de ese derecho. Ver los comentarios al respecto en Moreira Alves, "A formação romanística de Teixiera de Freitas e seu espíritu innovador", cit., 25-29. Por lo mismo criticó duramente a Seabra por haber incluido en su proyecto de Código Civil para Portugal normas propias de un código de procedimiento. Para todo, Orlando de Carvalho, V., "Teixeira de Freitas e a unificação do direito privado", en Schipani (dir.), Augusto Teixeira de Freitas e il diritto latinoamericano, cit., IO5 y Io6, n. I925-1929. Lo anterior se entiende sin perjuicio del conocido propósito de FreitaS de reunir el derecho civil y el comercial en un solo texto. También es importante considerar que, pese a su apego al derecho romano, en su Introdução a la Consolidaçâo, Freitas anotaría lo "muito" que han "estorvado a aplicação da verdadeira teoría" las ideas del derecho romano respecto a las acciones (cCviII).

49 Guzmán Brito, La codificación civil en Iberoamérica, cit., 506 y 507.

50 En cuanto a la concepción de las res publicae el Código, en el Libro iI: Dos bens, Título único: Das diferentes classes de bens, Capítulo III: Dos bens públicos e particulares, distingue entre los bienes públicos y los particulares, disponiendo el artículo 65: "São públicos os bens do domínio nacional pertenecentes à União, aos Estados, ou aos Municípios. Todos os outros são particulares, seja qual for a pessoa a que pertencerem". Por su parte, el artículo 66- I considera bienes públicos a los "de uso comum do povo, tais como os mares, rios, estradas, ruas e praças". El artículo 68 además precisa: " $O$ uso comum dos bens públicos pode ser gratuito, ou retribuído, conforme as leis da União, dos Estados, ou dos Municípios, a cuja administração pertencerem". 
Esta conclusión, que puede parecer lógica, debe, sin embargo, tropezar con que el mismo Beviláqua, al comentar su código, anota bajo la norma en cuestión (que establece que los bienes de uso común del pueblo son del dominio nacional de la Unión, los estados o los municipios) que ellos "pertencem a todos (res communes omnium). O propietário desses bens é a coletividade, o povo"; y uno entonces podría imaginar a un actor popular en su defensa. Sin embargo, estará lejos de ser esta una idea compartida por el jurista.

En efecto, después de declarar que las cosas de uso común del pueblo son también de dominio del pueblo el jurista agrega, a secas, que a la "administração pública estão confiadas a sua guarda e gestão" ${ }^{5}$, sin considerar la co-participación de un actor popular.

$\mathrm{Y}$ a mayor abundamiento, incluye en el código una norma que, por palabras de su propio autor, "prohibió" o "derogó" el uso de las acciones populares en materia civil. Se trata del artículo i 85 del proyecto del código que exigió, para proponer una acción en juicio, tener en ella un interés legítimo y, en su parágrafo único, que el interés moral sólo autorizaba la acción cuando tocase directamente al autor o a su familia; norma que generó, en el seno de la comisión revisora del proyecto, una ardua discusión entre Clóvis Beviláqua y el comisionado Andrade Figueira, precisamente en relación a las acciones populares ${ }^{2}$.

La discusión estuvo centrada básicamente en lo siguiente: para el comisionado Andrade Figueira no era comprensible "abolir" con esta norma, en el ámbito del derecho civil, a las acciones populares ya existentes en el derecho portugués y propio, por lo demás, de un Estado democrático, como se pretendía fuese el nuevo Estado brasileño. Para Clóvis Beviláqua, por el contrario, las acciones populares no debían "mantenerse" dado que, como en toda sociedad moderna, ya no se justificaban considerando que ellas se habían "transportado" del derecho civil al derecho criminal o derecho de policía, etc. y, en consecuencia, se habían "transformado" en "acciones públicas" cuya iniciativa corresponde exclusivamente a las autoridades y no al simple ciudadano.

La discusión comenzó cuando, al analizar la mencionada norma, la Facultade Livre de Direito do Rio de faneiro informó que, en su opinión, la norma regulaba

5I Ambos textos en Clovis Beviláqua, Codigo Civil dos Estados Unidos do Brasil, ed. histórica, Rio de Janeiro, Francisco Alves, I974, en los comentarios al artículo 66.

52 La discusión aparece transcrita en Ferreira Coelho, Codigo Civil dos Estados Unidos do Brasil, cit., I06-I 27 ; y puede ser confirmada directamente además en Projecto do Codigo Civil Brazileiro. Trabalhos da Comissão Especial da Camara dos Diputados, Rio de Janeiro, Imprensa Nacional, I902, t. IV, 278, y especialmente 2 I8-222. También aquí, en las notas, se transcribirán las partes más relevantes de dicha discusión. Conviene advertir que muchas palabras se escribían de manera distinta a la actual. Por ejemplo, las palabras ação y ações aparecen escritas con dos letras 'ç' juntas; el apellido del jurista Corrêa Telles, aparece escrito con dos letras 'l' juntas, etc., que mantendremos en su versión original. Por el contrario, hemos preferido indicar con un "(sic)" cada vez que constatamos errores del redactor de las sesiones al escribir el nombre de juristas, especialmente extranjeros, citados por Clóvis Beviláqua al fundar su propuesta de código civil. 
una materia puramente procesal (sobre la cual a los estados no competía legislar) y además que el derecho a proponer la acción debía ser libre pues sólo la sentencia decidiría si en ella tuvo o no interés legítimo quien la ejercitó. Para rebatir la primera apreciación Clóvis Beviláqua explicó el estado de la cuestión en la doctrina extranjera (citando a Windscheid, Chironi y Gianturco, aun cuando fueron muchos más los autores consultados, incluidos varios de la pandectística alemana) ${ }^{53}$, y para la segunda utilizó un ejemplo con el objeto de demostrar que le parecía "uma verdadeira aberração" permitir que todos pudiesen proponer una acción, tuviesen o no interés para ejercerla54.

Esta discusión llamó la atención del comisionado Andrade Figueira quien, más tarde (en la sesión de trabajo de la Comisión Especial de la Cámara de Diputados, del día 2 I de octubre de I90I) criticó también la citada disposición por abolir, en materia civil, el uso de los instrumentos populares. Su discurso fue el siguiente:

Esta disposição não pode figurar no código civil de uma República democrática, que prometeu progresso, porque isto é um progresso de caranguejo (riso).

O direito do Imperio dava a ação denominada popular a qualquer pessoa do povo para reivindicar tudo quanto fosse de uso público.

53 En esta sesión Clóvis Beviláqua, en síntesis, sostuvo que afirmar que la norma es "puramente procesal" es un "equívoco" que no ha considerado que el derecho a la acción se presenta a los ojos del jurista como dos "momentos" de una misma "idea", como dos "aspectos" de un mismo "fenómeno", en que para reintegrar el derecho o el interés que la ley protege y que ha sido violado es necesario que ese interés realmente exista. Si el proyecto, en su artículo I 84, establecía que todo derecho estaba provisto de una acción, es "indispensable" completar el pensamiento estableciendo las condiciones subjetivas esenciales para que la acción pueda ser propuesta. Según doctos juristas, las condiciones de ejercicio de la acción serían los siguientes: el interés de accionar (que el proyecto consagra en el artículo i85); la calidad para accionar (art. I84) y la capacidad para estar en juicio. Agrega: "Evidentemente, só ao direito material, e entre nós ao direito nacional e não ao regional, cabe fixar as condições dessa capacidade, porque direito sem ação é um conceito falbo, é uma aspiração, um desejo desprovido de condições de realizabilidade", y más adelante, que "o assunto está situado justamente na fronteira do direito material, oferecendo o ponto de conexão entre ele e o processo, e não tendo observado que também os civilistas expõem a matéria, como é fácil ver em Windscheid, Chironi, Gianturco, etc.". No dio lectura, esta vez, a las opiniones de estos juristas. Las obras que de ellos utilizó se pueden encontrar en la nota de Bibliografía que Beviláqua anotó bajo el artículo 76 en su Codigo Civil dos Estados Unidos do Brasil, cit., 3 I o. En la nota efectivamente se recuerda a estos tres autores y se menciona además a Espínola, Vampré, Mattirolo, Martinho Garcez, Jõao Monteiro, Demogue, Lagarmilla, Goudsmit, Dias Ferreira, Adherbal de Carvalho, Hedemann, Carvalho de Mendoça, Almachio Diniz, Martins Junior, Godofredo Vianna, Jhering, Dernburg y Fadda y Bensa (que conoce a través de las citas de WINDSCHEID).

54 Señala que "pela estranha doutrina do parecer, poderia o primeiro indivíduo, a quem tal ideia passasse pela cabeça, acionar mevio pelo [sic] que este devesse a Ticio, propor o divórcio de dois cônjuges, porque lhe parece que se acham nas condiçôes requeridas" por la ley. Agrega que "[o] absurdo é patente". Veáse en Reunión n. ${ }^{\circ}$ I I de la Comissão de Jurisconsultos según Proyecto do Codigo Civil revisto pela Comissão de Furisconsultos, en Ferreira Coelho, Codigo Civil dos Estados Unidos do Brasil, cit., I07-ıo9. 
Daqui qualquer pessoa do povo podia por meio de procurador propor uma ação, por exemplo, em Manaus, Matto Grosso, para reivindicar um próprio de uso público, para impedir que uma rua fosse tomada por alguém; para manter, emfim, o domínio público.

Este direito ia mais longe: admitia o princípio até mesmo para as ações prejudiciais.

Se um menor, por exemplo, não tem tutor, por que razão qualquer pessoa do povo não poderá requerer uma providência nesse sentido?

Quanto mesmo a certas servidões, o direito português também dava a ação popular.

Não interessava isso aos vizinhos, mas enfim podia interessar a qualquer cidadão, e ele podia requerer a supressão desses atravessadores.

Não conhece nada mais conveniente em uma República do que conservar os direitos populares, salvo se é uma República para uma raça privilegiada55.

La declaración es bastante ilustrativa a nuestros fines:

I. Se reconoce que las acciones populares se aplicaban en Brasil gracias a la vigencia del derecho portugués; idea que reiterará en la siguiente sesión en que se discutió el tema, al decir que la norma en cuestión "Proscreve as ações populares que nós já tínhamos no direito bizantino da monarquia".

2. El objeto que estas acciones tenían era "amplio", pues, si bien servían a mantener y reivindicar "todo" cuanto fuese del "uso publico", también podían ejercerse frente a hechos perjudiciales, para proteger a menores sin tutor y también respecto a ciertas servidumbres;

3. El legitimado activo era "cualquier persona del pueblo" o "ciudadano", sin limitaciones respecto al lugar donde se genera el hecho y el lugar de domicilio de quien motiva la acción.

4. Se puede deducir que los fundamentos para mantener a las acciones populares en el ordenamiento civil serían, en primer lugar, que en democracia cualquier persona puede accionar para tutelar aquellas cosas que tienen justamente un uso común de todos (y, con ello, se ampara el dominio público); y segundo, que la protección sería más eficiente, pues si bien ciertos hechos pueden suscitar poco interés en los "vecinos", podían, en cambio, existir ciudadanos atentos a poner fin a los hechos contrarios a derecho.

55 Declaración textual en la Reunión n. ${ }^{\circ}$ i I de la Comissão de furisconsultos en Ferreira Coelho, Codigo Civil dos Estados Unidos do Brasil, cit., ıo9. 
5. No se reconoce existir razón alguna para abolir del Código Civil estas acciones.

6. Las acciones populares eran una institución democrática, como debía ser la nueva república de Brasil.

7. Por todo lo anterior y especialmente tomando en consideración la naturaleza de los bienes a tutelar, si las acciones populares ya "se tenían" en el país, su abolición no constituía ningún "progreso" en relación al "derecho del imperio", como se esperaba fuese el Código Civil.

\section{La influencia de la normativa y doctrina europea de la época en los argumentos de Beviláqua contrarios a la acción popular}

En la sesión del 30 de octubre de I90 I Clóvis Beviláqua se hace cargo de las objeciones del comisionado Figueira Andrade y reitera a la Comisión su propuesta de mantener la citada disposición y, con ello, no consagrar en el Código Civil instrumentos populares, por los siguientes argumentos.

En primer lugar, el legislador brasileño apeló al origen de la norma y a que ella "obedeceu aos bons princípios ensinados pelos mestres". La fuente legislativa directa utilizada fue el artículo 36 del Código de Procedimiento Civil del Reino de Italia (I 865) que señalaba que "Per proporre una domanda in giudizio [...] è necessario avervi interesse"; interés al cual Beviláqua había agregado el calificativo de "jurídico" en atención a las consideraciones de autores extranjeros como Gianturco (y con sus citas a Jhering) $)^{56}$, Manfredini y el nacional Jõao Monteiro ${ }^{57}$. Respecto a la opinión de este último jurista, Andrade Figueira hizo saber sus "sospechas" dado su conocido perfil democrático $5^{8}$.

En segundo lugar, Beviláqua argumentó que las acciones populares (privadas y públicas) propias del derecho romano no se justificaban en la organización política moderna y que sólo era comprensible que existieran en aquellos Estados (como en Roma) que presentaban una “organización no suficientemente desa-

56 Según los textos del Projecto do Codigo Civil Brazileiro, cit., Iv, 22 I, argumenta Beviláqua, C. en relación a la norma italiana: "A este artigo foi acrescentada uma ponderação de Géan Turco (sic), um dos mais notáveis civilistas da Itália contemporânea", y procede a la lectura de tal ponderación: "Não pode propor uma ação senão quem tiver interesse jurídico na reintegração ou no reconbecimento do direito; de onde Yherving (sic) dizer que os direitos são interesses protegidos pela lei. $O$ interesse pode ser material ou moral: o interesse material dá sempre direito a intentar ação civil; o moral, ao contrário, somente quando toca diretamente ao autor ou à sua família". Considera que el principio es el "corriente" en otros juristas extranjeros y nacionales. Continúa la lectura: "Para que a potestas agendi se converta correta e proveitosamente na ratio agendi, requer-se no agente o concurso das quatro condições seguintes: a existência de um direito, o interesse de agir, qualidade para agir e capacidade de agir". Hemos confirmado el primer párrafo en Gianturco, E., Istituzioni di diritto civile italiano, Firenze, Barbera, I90 I, 343 (último párrafo).

57 Ver párrafo de Manfredini que Beviláqua, C. lee en Projecto do Codigo Civil Brazileiro, cit., 22 I. De Jõao Monteiro no lee texto alguno.

$5^{8}$ Ibíd. Dice: "E suspeito, já é republicano". 
rrollada" y donde, en consecuencia, resultaba indispensable que los particulares velasen por los intereses públicos. También aquí el comisionado Andrade Figueira hace una interrupción para destacar que por la misma razón expuesta era necesario mantener la institución en un país naciente como Brasil59.

En tercer lugar, Beviláqua señaló que las antiguas acciones populares habían "desaparecido por completo" de la "organización jurídica moderna” para ser "trasladadas" o "transportadas" desde el derecho civil al derecho criminal ${ }^{60}$, a las normas de policía, a las competencias municipales o, en algunos casos, como ofensas a derechos individuales ${ }^{61}$. Habría existido una "transformación" de las acciones populares en acciones "públicas" -dice Beviláqua-, o más bien "oficiales", lo interrumpe Figueira Andrade ${ }^{62}$.

Recordemos la similitud con el pensamiento de Winsdcheid: "L'attuazione dell'ordinamento relativo al godimento delle cose assegnate all'uso comune ha luogo o per provvedimenti di polizia, o coll'accordare una ragione privata verso il contravventore. Il primo modo non appartiene al diritto privato..." ${ }^{6}$, y de esta manera, no deben ser reguladas en el Código Civil.

59 Transcribo del Projecto do Codigo Civil Brazileiro, cit., 22 I: "As ações civis populares [...] existiram no direito romano e dele passaram para as legislações dos países que surgiram pelo esphacelamento do império dos Césares. No Direito Romano, apresentavam duas formas: as chamadas populares publicas, $e$ as denominadas populares privadas. Toda vez que surgia uma ofensa aos bens públicos, podia alguém intentar, contra o ofensor, uma ação que tinha por fim principal impor-lhe uma multa em favor daquele que propunha a ação.

"Esta era a feição privada da ação popular.

"Outras vezes, ela podia nascer de um ato do próprio magistrado ou de qualquer cidadão que agisse como o Estado ou o município, e então é que se chamava ação pública. Uma e outra, com o correr do direito, fundiram-se formando um todo único, as ações populares. Isto, porém, se compreende em um estado de direito em que a organização política não está suficientemente desenvolvida, de modo que seja indispensável que os particulares estejam velando pelos interesses públicos".

6o Señala varias normas del Código Penal de i830, referidas a las penas de prisión o multas aplicables frente a hechos como los siguientes: incendiar edificios y construcciones, almacenes, archivos, fortificaciones, arsenales, embarcaciones o navíos pertenecientes a la Nación (art. I39); destruir o dañar cualquier parte de una calle o vía de comunicación de uso público, obstaculizando o interrumpiendo el tránsito por ella, remover o inutilizar los objetos destinados a garantizar su seguridad (art. I 52); dañar las líneas telegráficas de la Nación o de los Estados y derribar o destruir puentes etc. (art. I 53); envenenar fuentes públicas (art. I6I); corromper o ensuciar el agua potable de uso común (art. I62); demoler o destruir edificios de la Nación, estado o municipio (art. 327); destruir o dañar monumentos, estatuas u otros objetos destinados a la decoración o recreo público (art. 328), etc. El jurista agrega los artículos 378 y 389 para la defensa de las cosas públicas, pero no los lee. Tampoco hemos podido acceder a ellos. La iniciativa de estas acciones corresponde al Ministerio Público exclusivamente.

6I Explica al respecto: "O que nesse domínio ficou para a iniciativa dos particulares, apresenta-se com a forma ordinária de proteção ao direito individual. Assim, quando eu quero ter a minha parte no gozo de um logradouro público, e sou impedido de exercer esse meu direito, concede-me a lei um recurso que o garante, mas neste caso o interesse individual é manifesto, e a espécie entra na regra geral".

62 Los textos en comillas son traducciones del portugués.

63 WindscheId, Diritto delle Pandette (I925), cit., 25-27 (y nota I 5). 
En cuarto lugar, el legislador argumentó que también Teixeira de Freitas -al comentar la obra Doutrina das acções de Corrêia Telles- había observado este fenómeno de "transporte" de las acciones populares del derecho civil a otras ramas del derecho cuando señaló que restringir las acciones populares a los dominios del derecho civil era no sólo limitar sino menguar tal institución. Sabemos que Freitas estaba parcialmente de acuerdo con que se trataba de una limitación de las acciones al derecho civil. Tampoco es tan exacto que Freitas "condena o Código do Processo pela feição que deu ao instituto", como afirma Beviláqua, y, si así fuera, lo que se discutía en el fondo era si mantener o no estas acciones en el derecho civil, y no en que código convenía su regulación, si esta aplicación se aceptaba. Beviláqua justamente se refirió a que las antiguas acciones o interdictos romanos pasaron a otras ramas del derecho, pero el punto justamente estaba en que esas ramas eran, primero, distintas al derecho civil y, segundo, de iniciativa de la autoridad (y no del actor popular). Por el contrario, si Freitas se refirió a la regulación del instituto lo hizo más bien en el entendido de que, aceptando su aplicación en el derecho civil y en el derecho criminal de la República, la definición de Corrêia Telles resultaba limitada pues no consideraba a estas últimas. En fin, no señaló jamás que las acciones destinadas a la protección de las res in usu publico debieran ser abolidas del derecho civil brasileño, como de alguna manera puede estimarse quiso Beviláqua hacer aparecer.

Beviláqua afirma que Freitas coincidiría con sacarlas del Código Civil y llevarlas a un código del proceso, sin ahondar en lo realmente importante, es decir, si era o no partidario de ellas (y sus argumentos), con independencia del código que debiera regularlas. $\mathrm{Y}$, repetimos, de los textos analizados no nos resulta que para Teixeira de Freitas "estas acções devem ser acções publicas" -como concluye su discurso Beviláqua-, pues bien sabemos que los conceptos de lo público en ambos es distinto. Para Beviláqua "públicas" significaba acciones de exclusiva iniciativa del Ministerio Público (o de autoridades) y cuyo ámbito de aplicación escapaba al derecho civil. Freitas, en cambio, aceptaba las acciones populares (como aquellas que competían a cualquiera del pueblo), y ejercitables, a mayor abundamiento, "no sólo" en derecho civil sino en otras ramas del derecho, como el derecho penal. Nótese además que los ejemplos que daba Freitas del derecho penal eran también distintos a los que daba Beviláqua pues, mientras en los de este el actor era efectivamente "cualquiera del pueblo", en los ejemplos de Beviláqua eran acciones sólo de iniciativa de la autoridad. Andrade Figueira -quizás por lo mismo- interrumpió a Beviláqua con un aplauso y agregó que "É doutrina de Teixeira de Freitas" conceder acción popular incluso para defender la esclavitud o para proteger a un menor.

Hubo aun una última sesión en la que Beviláqua volvería al tema, reiterando que Andrade Figueira pretendía mantener una institución desaparecida por completo de la organización moderna, presentando en apoyo de su posición las 
opiniones -a las cuales dio lectura- que Goldschmidt ${ }^{64}$ y Mattirolo ${ }^{65}$ dedicaban a la "desaparición" de las acciones populares ${ }^{66}$.

En los párrafos que Beviláqua lee resulta patente siempre la misma idea: las acciones populares desaparecieron del derecho moderno del continente europeo por estar en contra del principio en virtud del cual la acción penal es esencialmente pública y debe ser ejercitada en consecuencia sólo por el Ministerio Público. Desde el punto de vista del derecho civil, la institución, además, ya no se puede justificar en el Estado moderno (distinto al romano en que cada ciudadano era parte integrante del mismo) pues ahora se está frente a una persona jurídica (distinta a los miembros que la componen) que ha reservado exclusivamente el ejercicio de la acción en funcionarios públicos.

Nótese la similud de lo expuesto con las ya citadas palabras de Dernburg ${ }^{67}$ en relación a los interdictos populares para la defensa de las res in usu publico:

64 Beviláqua, C. lee (o traduce) en portugués algunos párrafos del $\$ 90$ del volumen I del Curso da Pandectas, que se pueden consultar en Ferreira Coelho, Codigo Civil dos Estados Unidos do Brasil, cit., i I6. Podemos sintetizar los párrafos elegidos por Beviláqua de la siguiente manera: la acción popular sería aquella que resulta de contravenciones o disposiciones edictales dictadas en el interés general y que podían ser, en consecuencia, intentadas por cualquier persona aunque no haya sido personalmente lesionada y en cuyo patrimonio entrará la multa cobrada al contraventor. Después se agrega que "[e]n nuestro derecho, la mayor parte de los objetos que entraban en el círculo de las acciones populares son de la competencia de la policía”. Llama la atención que Beviláqua recalcase, al iniciar su lectura, que se trataba de palabras de un "romanista.

65 Beviláqua lee (y traduce) algunos párrafos del Direito fudiciario Civil, vol. I, n. 32. Los párrafos elegidos pueden consultarse en portugués en Ferreira Coelho, Codigo Civil dos Estados Unidos do Brasil, cit., i i 6 y i i 7; y en español en Matтirolo, L., Tratado de derecho judicial civil, Madrid, Reus, I930, t. I, en la traducción realizada por Eduardo Ovejero y Maury. Los párrafos elegidos decían, en síntesis, lo siguiente, para lo cual citamos textual la obra en español: "El derecho moderno del continente europeo, por regla general no admite las acciones populares. La popularis accusatio y la acción popular penal, encaminada a obtener la condena del culpable a pena corporal o pecuniaria, son contrarias al principio fundamental de nuestro derecho según el cual la acción penal, esencialmente pública se ejercita exclusivamente por el Ministerio Público. Y también en la esfera del derecho puramente civil, el Estado Moderno, en su evolución histórica, se ha venido formando de manera muy distinta del Estado antiguo: de tal suerte que si, entre los romanos, todo ciudadano era parte integrante del Estado y asumía en muchos casos su representación, promoviendo las acciones correspondientes a la comunidad, hoy el Estado constituye una persona enteramente distinta de la de los ciudadanos particulares que lo componen y el ejercicio de las acciones civiles que le corresponde se reserva a los funcionarios, especialmente delegados para reivindicar y defender sus derechos”. Las palabras aumentadas son aquellas en las que Beviláqua solicitó atención de la Comisión al leer.

66 También citó, pero no leyó, opiniones de Mancini y Monteiro. Considerando la influencia que Gianturco tuvo en la redacción del artículo I 76, nos parece pertinente citar sus ideas, extraídas de Gianturco, Istituzioni di diritto civile italiano, cit., 344: "Le azioni popolari, esercitate da privati cittadini per fare reintegrare diritti pubblici manomessi, di regola non sono più ammesse nel diritto moderno".

67 Dernburg, Pandette, cit. por Di Porto, "Interdetti popolari e tutela delle 'res in usu publico", cit., 504 . 
"Essi non sono stati ricevuti”, y las de Glück ${ }^{68}$ : "oggidì la cura dell'uso pubblico e la sua tutela d'ufficio spetta alle autorità amministrative dello Stato e del Comune".

Tras estas arduas discusiones, en fin, fue rechazada la enmienda del comisionado Figueira Andrade (de eliminar el parágrafo único de la norma) y el artículo fue aprobado.

El relator de esta última sesión, Frederico Borges, dejó constancia de su parecer en una nota que pasamos a transcribir de manera textual pues en ella se resume exactamente la doctrina de Beviláqua, a su vez "transportada" de la doctrina extranjera citada más arriba; y que en definitiva implicó que, en el Código Civil Brasileño (tal como pasó en Europa), primó la concepción abstracta del Estado y, en consecuencia (tal como sostiene Andrea Di Porto), resultó lógico eliminar un instrumento como la acción popular que importa, per se, un protagonismo del ciudadano en la tutela de las cosas de uso común y una concepción distinta de lo "público", del "pueblo" y del "Estado":

Hoje o Estado, as províncias e as comunas constituem pessoas distintas dos indivíduos que os compõem e o exercício das ações populares que interessam a essas pessoas jurídicas é confiado a oficiais ou funcionários especialmente incumbidos de velar pela defesa dos Direitos da coletividade. Por isso desapareceram do Direito Civil moderno as ações populares, cujo objeto em parte entrou para a esfera do direito criminal, passou a constituir matéria de prescrições policiais, em parte converteu-se em direito pertencente aos indivíduos, quando são estes diretamente lesados, e em parte constitui direito das coletividades, como pessoas jurídicas de direito público. Não tinham mais uma função apreciável a exercer, no direito civil moderno, as ações populares ${ }^{6}$.

En su edición comentada del Código Civil, Clóvis Beviláqua anota, al pie de la señalada norma (art. $7^{\left[7^{[0]}\right.}$ ), que con ella "se puso término" a la controversia relativa a la persistencia de las acciones populares del derecho romano para la defensa de los bienes públicos ${ }^{7 \mathrm{I}}$ y que, convertidas en "públicas" (cualquiera sea el ámbito en que se apliquen), dejan de ser populares, pues son de iniciativa ex-

68 GLÜck, Commentario alle Pandette, cit. por Di Porto, "Interdetti popolari e tutela delle "res in usu publico"”, cit., 503 y 504.

69 Ver Ferreira Coelho, Codigo Civil dos Estados Unidos do Brasil, cit., i i 7 y i i 8.

70 El texto oficialmente aprobado fue el siguiente: art. 76: "Para propor, ou contestar uma ação, é necessário ter legítimo interesse econômico ou moral. Parágrafo único. O interesse moral só autoriza a ação, quando toque, diretamente, ao autor ou à sua família”.

7 I “Outra controvérsia, a que pôs termo, foi a referente à persistência das ações populares, que, no Direito Romano, tinham por objeto a defesa dos bens públicos. Na organização jurídica moderna, os atos, que davam causa às ações populares, passaram a constituir crimes reprimidos pelo Código penal, sendo a matéria ora de leis de policia, ora de posturas municipais, e, algumas vezes, ofensas a direitos individuais". En Beviláqua, Codigo Civil dos Estados Unidos do Brasil, cit., I, I927, 3 I 2. 
clusiva de la autoridad. La doctrina de la época (Espínola ${ }^{72}$ y Ferreira ${ }^{73}$ ) coincide con el pensamiento de Beviláqua, para lo cual recurre profusamente, como él, a Gianturco y otros comentadores de la norma italiana que sirvió de modelo al artículo 76 .

\section{Conclusiones}

Este trabajo revisa cómo fueron concebidas las acciones (e interdictos) populares en el proceso de codificación civil brasileño del siglo xix, y específicamente las romanas creadas para protección de algunas res publicae.

Se sugiere que Teixeira de Freitas, si bien no consagró acciones populares en el Codigo civil. Esboço, sería partidario de ellas, cuando se amenazare o afectare una cosa de uso común. $\mathrm{Al}$ respecto resultan ilustrativas las notas que Teixeira dedicó a la obra Doutrina das ações del conocido jurista portugués José Homem Corrêa Telles y que ajustó al Foro de Brasil, donde el jurista coincide en que no existe impedimento alguno para el ejercicio de las acciones populares destinadas a la usurpación y conservación de las cosas públicas, incluyendo en ellas, justamente -como diría Di Porto-, aquellas destinadas al uso común, como los lugares, calles, mar y ríos públicos. Y se plantea que quizá no consideró estos instrumentos en su código, pues buscando sólo codificar el derecho civil, Freitas excluirá de sus obras todo lo relativo a las acciones.

Clóvis Beviláqua, el redactor del Código Civil Brasileño de ı196, claramente no fue partidario de estos instrumentos, influenciado especialmente por la pandectística europea y por procesalistas italianos. Se confirma que también en Brasil el abandono legislativo por las acciones e interdictos populares se debió a la noción abstracta del Estado y a la influencia de la pandectística, como afirmó Di Porto para el proceso de codificación civil europeo.

En todo caso, no resultará tan exacto que con el artículo 76 se haya "puesto fin” en Brasil a la aplicación de las acciones populares para la defensa de las cosas comunes, puesto que parte de la doctrina las siguió considerando vigentes (no

72 Según Ferreira Coelho, Codigo Civil dos Estados Unidos do Brasil, cit., i 26, el jurista Eduardo Espínola, en sus Breves annotações ao Codigo Civil Brasileiro (Bahía, igr8-i930), señaló: “Com o parágrafo único do art. 76 se procurou suprimir toda a dúvida, quanto à persistência das ações populares". El mismo autor, ahora consultado directamente en Espínola, E., Manual do Codigo Civil Brasileiro, Parte Geral. Dos factos juridicos, Rio de Janeiro, Jacinto Ribeira Dos Santos, I923, vol. III, P. I. ${ }^{\text {a }}$, I34, señala que las acciones populares en Brasil sólo se pueden ejercer en casos excepcionales y siempre fuera del derecho privado. Para su aplicación se requiere de su consagración por leyes especiales, como ocurría en materia electoral.

73 Y agrega Ferreira Coelho, Codigo Civil dos Estados Unidos do Brasil, cit., en la misma página I 24: "con la organización moderna que adoptaron las naciones civilizadas no hay razón para confiar a cada ciudadano la provocación y promoción de los procesos de acción pública, quedando así libre el Poder Judicial de la anarquía, provocada muchas veces, o casi siempre, por el odio partidario de potentados ignorantes" (trad. libre). 
obstante el Código Civil) ${ }^{74}$ y además, veinte años más tarde, fue consagrada la acción popular (pese a la oposición también aquí del jurista75) a nivel constitucional para la defensa del "patrimonio público" (eso sí, sólo para pedir la nulidad de ciertos actos) y, desde I988, para la defensa del "medio ambiente", bien que se eleva coherentemente -y aquí está el fundamento de la popularidad- a un "bem de uso comun do povo".

\section{Bibliografía}

Beviláqua, C., Codigo Civil dos Estados Unidos do Brasil, ed. histórica, Rio de Janeiro, Francisco Alves, I974.

Bonfante, P., Istituzioni di diritto romano, Milano, Vallardi, I932.

Bonfante, P., Storia del diritto romano, Roma, Istituto di Diritto Romano, R. Università, I934, 2 vols.

Bruns, C. G., Le azioni popolari romane, prefacio y trad. Vittorio Scialoja, en Scialoja, V. (dir.), Studi Giuridici, Roma, Anonima Romana Editoriale, I933, vol. I.

74 Apenas dictado el Código, algunas voces aisladas argumentaron que el artículo 76 sólo impedía ejercer acciones de carácter civil, pero no las criminales ni administrativas. Nos referimos a Carvalho Santos y Barbosa de Campos Filho, P., quienes citan, a su vez, a De Camargo Mancuso, R., Ação popular, 3. ${ }^{\text {a }}$ ed., Sao Paulo, Revista dos Tribunais, I998, 5 I.

E incluso más, al menos para Pontes de Miranda, cuando en 1939 se dicta el Código de Procedimiento Civil de Brasil que repitió, con algunas modificaciones, el inciso primero del artículo 76 c.c. y omitió su parágrafo único, este "corte" significaba la derogación de dicho parágrafo y que, en consecuencia, era posible proponer o contestar una acción como popular pues "desde que o direito material as tenha, não se lhes poderia negar o ingresso em juizo, através dos remédios processuais, próprios ou gerais". Ver en Pontes de Miranda, F., Comentários ao Código de Processo Civil, Rio de Janeiro, Forense, I947, I, I I 2.

75 A sólo 20 años del fuerte rechazo que la institución tuvo en el Código Civil ella será consagrada -ahora a nivel constitucional (Constitución de 1934)- para requerir judicialmente la nulidad de los actos lesivos al "patrimonio público". El texto del artículo I 13 inciso 38 señalaba: "Qualquer cidadão será parte legítima para pleitear a declaração de nulidade aou a anlulação dos atos lesivos do patrimônio da União, dos Estados ou dos Munícipios".

Su consagración, sin embargo, no estuvo exenta de censuras y vale la pena citar también aquí al principal opositor: Clóvis de Bevilácua. En esta oportunidad su rechazo se fundó en que las acciones populares podían provocar "inconvenientes, que a bõa organização do Ministerio Publico evita. Para funções dessa classe, a sociedade possui órgaõs adequados, que melhor as desempenharam do que qualquer do povo". Texto extraído de De Camargo Mancuso, Ação popular, cit., 52.

Como vemos, el jurista no sólo reitera que el Estado es el que debe tutelar "exclusivamente" las lesiones al patrimonio público, sino que además agrega que ese sistema será siempre "mejor" que la defensa que podría desempeñar el actor popular, descartando que este pueda actuar junto a la autoridad. 
Capogrossi, L., "Interdetti”, en Enciclopedia del Diritto, Milán, Giuffrè, ı97 I, t. XXI, 9OI-927.

Carvalho Santos, J. M. (dir.), Repertório Enciclopédico do Direito Brasileiro, coadyuvado por José de Aguiar, Rio de Janeiro, Borsoi, I947, vol. II.

Corrêa Telless, J. H., Doutrina das ações, acomodada ao Fôro do Brasil por A. Teixeira de Freitas, Rio de Janeiro, Garnier, I902.

De Carvalho, O., "Teixeira de Freitas e a unificação do direito privado", en Schipani, S. (dir.), Augusto Teixeira de Freitas e il diritto latinoamericano, Atti del Congresso di Roma, I, Padova, Cedam, I988, Io I-I 54.

De Camargo Mancuso, R., Ação popular, 3. ${ }^{a}$ ed., Sao Paulo, Revista dos Tribunais, I998.

Delgado Schneider, V., "La protección del medio ambiente a través de las acciones populares del artículo 948 del Código Civil de Andrés Bello: un estudio histórico-comparativo", en Martinic, M. D., y Tapia, M. (eds.), Sesquicentenario del Código de Andrés Bello. Pasado, presente y futuro de la codificación, Santiago, LexisNexis, 2005, 907-937.

Dernburg, H., Pandette, trad. ital. de la $6 .^{\mathrm{a}}$ ed. por F. Cicala, Torino, Fratelli Bocca, I906, vol. I, n. ${ }^{\circ}$ I.

Di Porto, A., "Interdetti popolari e tutela delle res in usu publico", en AA.vv., Diritto e processo nell'esperienza romana. Atti del seminario torinese in onore di $G$. Provera, Torino, 4-5 dic. I99 I, Univerità di Torino, Miscellanea dell'Istituto Giuridico I, Napoli, Jovene, I994.

Di Porto, A., La tutela della "salubritas" fra editto e giurisprudenza I, Il ruolo di Labeone, Milano, Giuffrè, I990.

Di Porto, A., "O papel do cidadão na tutela do ambiente”, Revista Brasileira de Direito Comparado, Rio de Janeiro, vol. I 2 (I992), I 54 ss.

Espínola, E., Manual do Codigo Civil Brasileiro, Parte Geral. Dos factos juridicos, Rio de Janeiro, Jacinto Ribeira dos Santos, I923, vol III, Parte I. a .

FADDa, C., L'azione popolare. Studio di diritto romano ed attuale, Torino, Utet, I 894. 
Ferreira Coelho, A., Código Civil dos Estados Unidos do Brasil. Comparado, comentado e analisado, Rio de Janeiro, Jornal do Brasil, I925, vol. I 3.

Freitas, A. Teixeira de, Código Civil - Esboço, Rio de Janeiro, Typographia Universal de Laemmert, I 864, 4 vols.

Freitas, A. Teixeira De, Consolidação das Leis Civis, Rio de Janeiro, Typographia Universal de Laemmert, I857, 527 p.

Gianturco, E., Istituzioni di diritto civile italiano, Firenze, Barbera, I 9o I.

GLÜck, C. F. v., Commentario alle Pandette, trad. ital. G. Fadda y P. Cogliolo, Milano, Società Editrice-Libraria, I905, L. XLIII, P. IV.

Guzmán Brito, A., Derecho privado romano, Santiago, Jurídica de Chile, i996, I.

Guzmán Brito, A., La codificación civil en Iberoamérica. Siglos XIX y XX, Santiago, Jurídica de Chile, 2000.

Jhering, R. v., Lo scopo nel diritto, trad. Mario G. Losano, Torino, Einaudi, I972.

Mattinolo, L., Tratado de derecho judicial civil, Madrid, Reus, I930, t. I.

Moreira Alves, J. C., "A Formação romanística de Teixiera de Freitas e seu espíritu inovador", en Schipani, S. (dir.), Augusto Teixeira de Freitas e il diritto latinoamericano, Atti del Congresso di Roma, I, Padova, Cedam, I988, 4I-50.

Pinto Ferreira, L., voz “ação popular”, Enciclopédia Saraiva do Direito, coord. R. Limongi França, São Paulo, Saraiva, I977, vol. I.

Pontes de Miranda, F. C., Comentários ao Código de Processo Civil, Rio de Janeiro, Forense, I947.

Projecto do Codigo Civil Brazileiro. Trabalhos da Comissãa Especial da Câmara dos Deputados, Rio de Janeiro, Imprensa Nacional, I902, t. Iv.

Ricсовоno, S., “Interdicta”, en Azara, A. y Eula, E. (eds.), Novissimo Digesto Italiano, Torino, Utet, I962, vol. viII, 793-798.

Sacchi, A., "Interdicta”, en Fiore, P. y Lucchini, L.(eds.), Il Digesto italiano, Torino, Utet, I 902-I906, vol. xIII, I 286-I 309. 
Schipani, S., "Actio de positis aut suspensis", en Schipani, S. (dir.), Derecho romano y unificación del derecho, Experiencia europea y latinoamericana (con especial atención a la responsabilidad extracontractual), Materali II, Roma, Università Tor Vergata, I999, I45-I 5 O.

Schipani, S., "Actionis de diectis vel efussis", en Schipani, S. (dir.), Derecho romano y unificación del derecho, Experiencia europea y latinoamericana (con especial atención a la responsabilidad extracontractual), Materali II, Roma, Università Tor Vergata, I999, I 5 I-I 76.

Schipani, S., "Dal diritto romano alle codificazioni latinoamericane: l'opera di A. Teixeira de Freitas (Prime osservazioni sulla nozione di "Consolidação" e sulla sistematica dei 'fatti')", en Società sassarese per le scienze giuridiche (ed.), Studi Sassaresi - serie 3, n. 5: Atti del Colloquio internazionale sul diritto romano, codificazioni e unità del sistema giuridico latino-americano (I977-78), Milano, Giuffrè, I981, 589 ss.

Windscheid, B., Diritto delle Pandette, trad. ital. C. Fadda y P. E. Bensa, Torino, Utet, I904.

Windscheid, B., Diritto delle Pandette, trad. ital. C. Fadda y P. E. Bensa, continuada por Bonfante, ayudado por Maroi, Torino, Utet, I92 5, vol. I. 